\title{
Analysis of Satisfaction of Small Cucumber Contract Famers in Predominantly Agriculture areas in Sri Lanka
}

\author{
Harshana PVS* \\ Department of Agriculture Economic, Ruhuna University of Sri Lanka, Sri Lanka
}

Submission: October 03, 2018; Published: January 05, 2019

"Corresponding author: Harshana PVS, Department of Agriculture Economic, Faculty of Agriculture, Ruhuna University of Sri Lanka, Mapalana, Kamburupitiya, Matara, Sri Lanka

\begin{abstract}
Contract farming is gradually increasing in last three decades in Sri Lanka. Contract farmers are the only investment with the possibility for producing infinite return to the organization. Thus, it is critically important to attracting best contract farmers to the organization as well as make effort to retain them in the organization too. Low retention rate of Contract farmer is a common problem in every agricultural organization. With the alternatives production, retention of contract farmer in an organization is challenging not much easy task. In case of retention of contract farmer, their satisfaction is remarkable factor. Therefore, identification of factors effect on retention and satisfaction of contract farmers has become a much controversial topic to that can be studied much deeper.

These studies based on identify the factors effect on retention and satisfaction of contract farmers in small cucumber cultivation. The study has been conducted through 90 contract farmers in three districts. According to the findings experience $(r=0.1299, p=0.0000)$ and job status $(r=0.0638, p=0.0000)$ are positively effect on satisfaction and retention but age $(r=-0.0048, p=0.0000)$ is negatively affected. Contract farmers satisfied with training program provided by organization, land preparation practices, yield in small cucumber cultivation. Poor farm gate price, timely not money receiving like organizational factors and difficult of pest controlling, harvesting reduce retention of contract farmer. Findings of the study enable the Companies management to understand the reason behind the lower level of retention in contract farming.
\end{abstract}

Keywords: Contract Farmers; Retention; Satisfaction

\section{Introduction}

With the ever-increasing competition of the agricultural business world, most of the private sector contracts farming providers are also in the phase of increasing their profits. The techniques of contract farming which are used for the profit enhancement is occasionally giving positive outcomes as well as negative outcomes. Efficiencies and productive farmer community vital assets for achieving a higher level of performance in an organization [1]. Satisfied farmer community leads to enhance effort to cultivation performance, so that maintaining of satisfied contract farmer in an organization is crucial factor. To maintain the well-being of an organization management tries to create a highly satisfied farmer community. Therefore, organizational management places a noticeable reliance on their individual farmer performance to gain higher productive cultivation $[2,3]$.

These conditions are leading the contract farmers in the organization to going through a condition of farmer's job satisfaction which directly affects day today cultivation practices. Together with these facts, there is a new trend in the agricultural academic societies in search of factors that are affecting the level of job satisfaction condition as well as searching the relationships among the job satisfaction conditions and the contract farmer's performances [4].
The aim of this research study is to identify the factors effect on job satisfaction level of the contract farmers on small cucumber cultivation in predominant agriculture areas such a s Ampara, Thabutthegama \& Pollonnaruwa in Sri Lanka. When a contract farmer satisfied about the farming contract they are tending to motivate to do higher effort to the cultivation performance. Ultimately it increases organizational overall performance by increasing continues proper supply to export market [5]. On the other hand, a satisfied farming community \& their effort \& commitment to cultivation practices are vital for successfulness of organizational goals \& objectives. Therefore, the address research problem of this study is that; Satisfaction factors which effect on contract farming [6].

\section{Problem Statement}

Small cucumber export market mainly depend on continues product supply to the market. The continues repetition of contract farming in small cucumber ensure continues small cucumber supply to the market. When there is an insufficient supply, company must import Small cucumber from India and USA and reexport by spending huge cost. Farmers are tending to renew their contract agreement when farmer are satisfied with the existing 
contract farming activities. Analysis of farmer satisfaction on small cucumber contract farming is vital to increase the profitability of the company [7-9].

During the past few decades, in this small cucumber export private company contract farmer's repetition of cultivating small cucumber level has decreased significantly. According to the Supply chain department's sources in 2016 since the organization has implemented lots of strategies changes to the contract farming of the organization, most of the farmers has faced various organizational challenges and those challenges has decreased the satisfaction level of the contract farmers of the organization. According to Bommanahalli and Rangappa, (2016) contract farmers found to be using improved farming practices in maize production. According to Aziri [10] research emphasize that contract farming enhances farmers knowledge, attitude \& agronomic practices about small cucumber farming.

As indicated by the Asian Development Bank (2008) a "farmerendeavor" association for industrialization of agribusiness can be deciphered as the model of agreement cultivating that is generally drilled in numerous nations. It is by and large acknowledged that economical, efficient, and impartially executed contract cultivating can bring advantages to the two ranchers and the endeavors [11$15]$.

\section{Justification of the Problem}

It is identified that satisfaction of contract farmers to work to achieve higher amount of cultivation \& repetition, as well as dissatisfaction of contract farmers will decrease the cultivation area \& increase the non-repetition. Because of dissatisfied contract farmers continuous small cucumber export is breaking that problem of the finally decrease the organizational profit \& reputation [16]. According to the Organization 2016 financial report it was then found a significant reduction in the repetition of small cucumber contract farming of the organization by $45 \%$ compared to the previous year (2015).

It was also found that there is a significantly higher percentage of small cucumber production deduction compared to the previous years and the previous record prevailing with the records of the organization. All in all, these all factors and figures are providing enough evidences for the occurrence of lower satisfaction level with the contract farmers of the organization [17-20]. As per the Asian Development Bank Report in 2015 underlined that farmer- endeavor organizations ought to be built up to pull in more speculations into horticulture and provincial regions, and to assemble a market-situated rural innovation augmentation framework. The administration has constantly considered contract cultivating as an essential intends to reinforce farmer- endeavor associations [21-23]. As indicated by the Lieping [24] the way that ranchers are unwilling to go into contract cultivating additionally captures the improvement of farmer- endeavor organizations. Numerous examinations additionally detailed that the satisfaction rate of agreement cultivating in the China was low [25].

\section{Objectives of the Study}

The researcher is trying to achieve the below mentioned objectives by conducting this research study [26].

\section{General Objective}

a) To study the existing small cucumber contract farming cultivation under leading export pvt. group of company and analysis the farmer satisfaction towards the of contract farming to reduce farmer dropout rate [27]

\section{Specific Objectives}

a) To ascertain the existing small cucumber contract farming under leading export company

b) To analysis of farmer satisfaction toward small cucumber contract farming.

c) To give recommendation and suggestion to enhance contact farming of small cucumber [28].

\section{Research Design and Research Methodology}

The key motive of this descriptive research method and the descriptive research design is mainly to investigate the relationship of the contract farmer's job satisfaction level and the impact of those job satisfaction levels towards the contract farming in small cucumber cultivation [29]. The specific organization selected for the simplification of the overall work was the main small cucumber export private company of Sri Lanka.

This research base on to seek the "Impact of contract farmer's satisfaction level on the small cucumber cultivation: a study of small cucumber export organization of Sri Lanka. Primary data was collected from pre-tested structured questioner, which specially design and given selected group. Secondary data was collected from previous researches, journals, and government publications etc which are specifically focused on the farmer satisfaction and the contract farming [30-33]. As mentioned in the conceptual model and as elaborated in the hypothesis also, the independent variables were the contract farmer 's satisfaction'. As per the dependent variable, the most significant variable of the research which was the 'small cucumber cultivation related performance' was used. It does mean whether repetition or not.

\section{Population, Sample and Sampling}

In this study to seek the influence of farmer satisfaction towards the small cucumber cultivation. Mainly focus group was the currently engaging farmers of the organization. Though it is obvious that the compilation of data from the all districts and making necessary data bases for the purpose of the accuracy of the data and the accuracy of the data interpretation when it comes to the generalization of the final results and discussions; the chosen study areas were restricted to the Ampara, Pollonnaruwa \& Thambutthegama districts due to the time limitation in collecting the data and the budget constraints of the study. After all the final sample of the study would be a compilation of the given below [34-38]. 


\section{Data Collection Techniques}

In a quantitative research there are several data collection methods, there two source of data such as Primary data and secondary data. Primary data gathered from actual research events. Secondary data gathered from previous articles, journals, government publications. According to this research secondary data was analyzed by a quantitative manner. Pre-tested questioner did help in achieving this task. It also could be two ways such as personally administrated and interview. Since the limitations pertaining to the research as well as to the researcher (time constraint and the budget constraint) the method which was used for the collection of data was that the use of pre tested questionnaire by interviewed of 20 contract farmers in one district for the purpose of obtaining the data has first been granted the required permission from the upper management of the organization [35].

The sample was selected through simple random sampling and the areas from the Ampara, Pollonnaruwa \& Thambutthegama districts were chosen through purposive sampling. The key motive of using the simple random sampling for the sample selection was that to maintain the accuracy of the data which has been generated and to increase the probability for the research to be published in peer reviewed journals or any relevant standard publication materials as a final step of the carrying out of a successful research [36].

\section{Results and Discussion}

\section{Frequency Distribution of Age}

According to the Pearson correlation test for age $r=-0.0048$ ( $95 \%$ confidence interval). When age is increasing job satisfaction will decrease. Have a negative correlation. There were $34.4 \%$ contract farmers in 31-40 years' age range. In the range of 41-50 age categories, there were $33.3 \%$ of the respondents, and in 51 60 years' category $24.5 \%$ of the contract farmers. It was observed that only $7.8 \%$ of the respondents were in the age range of above 60 years (Figure 1 ).

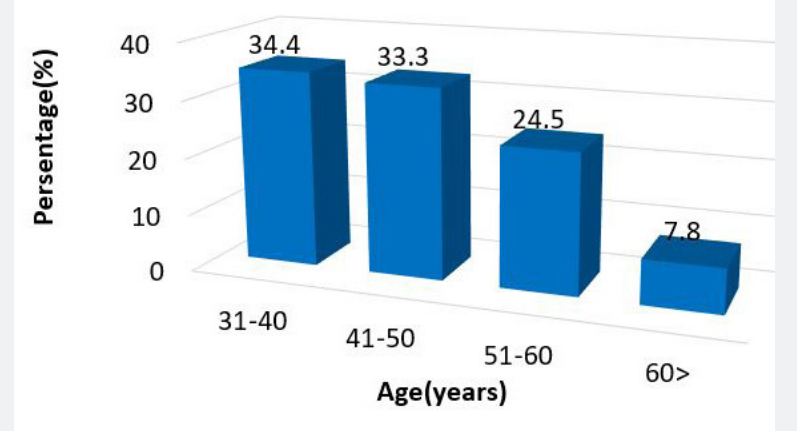

Figure 1: Frequency distribution of contract farmers with age.

\section{Frequency Distribution of Job status}

According to the analyzed data most of the contract's farmers (76\%) only engage with agriculture.24\% contract farmers doing agriculture simultaneously with other status such as government, private employment. According to the Pearson correlation value job status and job satisfaction has positive relationship. ( $\mathrm{r}=0.0638$, $\mathrm{p}=0.0000$ at $5 \%$ significant level) (Figure 2).

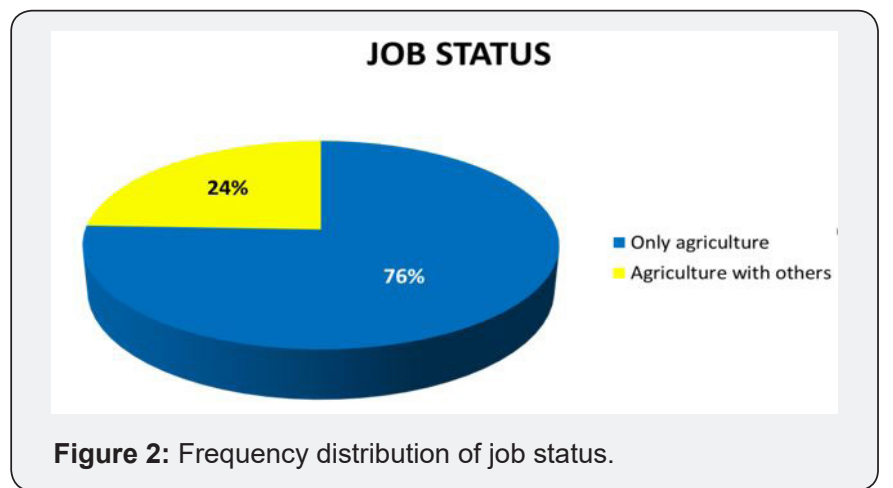

\section{Frequency Distribution of Civil Status}

$94 \%$ of contract farmers were married and only $6 \%$ of contract farmers were single (Figure 3).

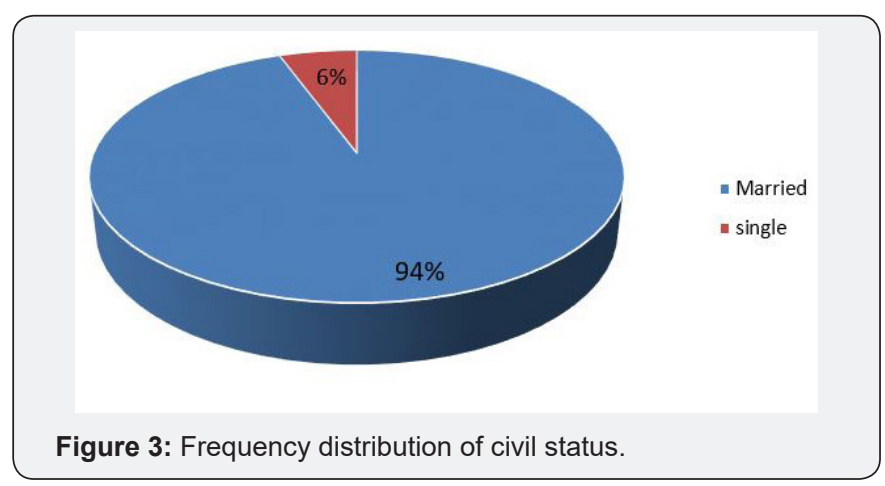

\section{Frequency Distribution of Agricultural Experience}

According to the sample $38.9 \%$ of farmers have $13-16$ years in agricultural experience. In the range of 9-12 experience categories, there were $33.3 \%$ of the respondents, and in 5-8 years category $16.7 \%$ of the contract farmers. It was observed that $8.9 \%$ of the respondents were in the $17-20$ range and only $2.2 \%$ of contract farmers above 21 years experiences (Figure 4).

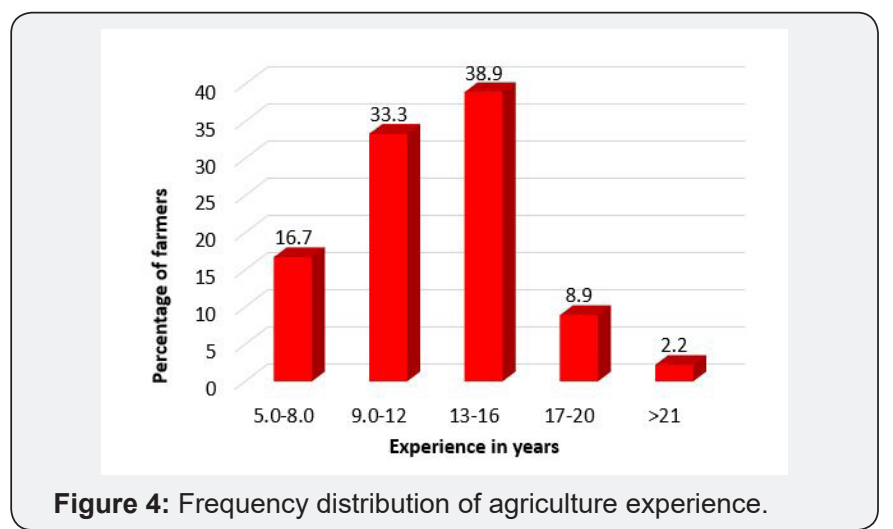

\section{Frequency Distribution of Experience in Small Cucum-} ber Cultivation

More than half (61.1\%) of contract farmers have 1-5 years' work experience in small cucumber cultivation.6-10 years it 


\section{Annals of Social Sciences \& Management studies}

was $26.7 \%$ and $11-15$ category there was $11.1 \%$ and only $1.1 \%$ contract farmers have 16-20 years small cucumber cultivation experiences. According to the correlation value $r=0.1299$ (at $95 \%$ confidence interval) experiences positively correlated with job satisfaction (Figure 5).

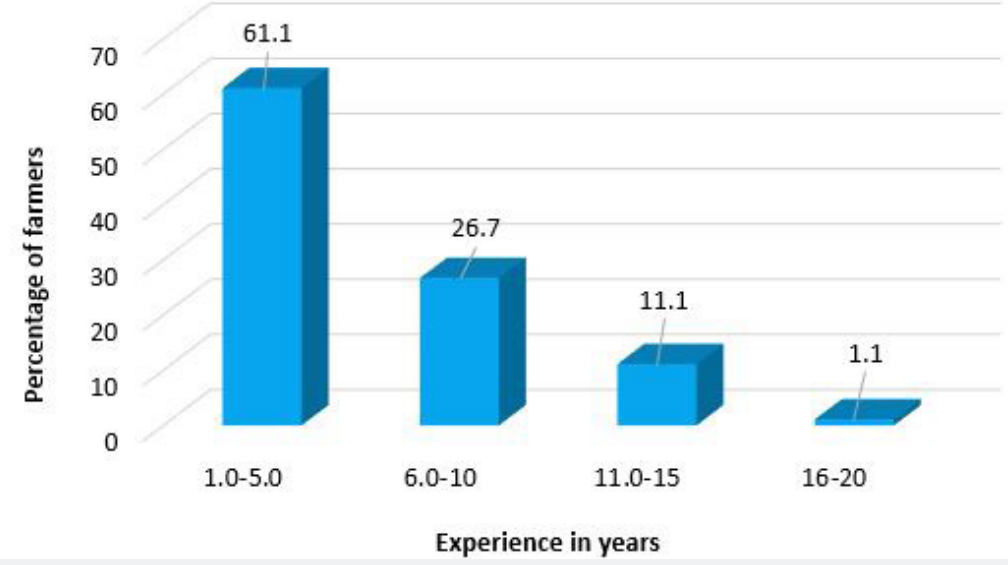

Figure 5: Frequency distribution of experience in Small cucumber cultivation.

Frequency Distribution of Different Cultivation Pattern

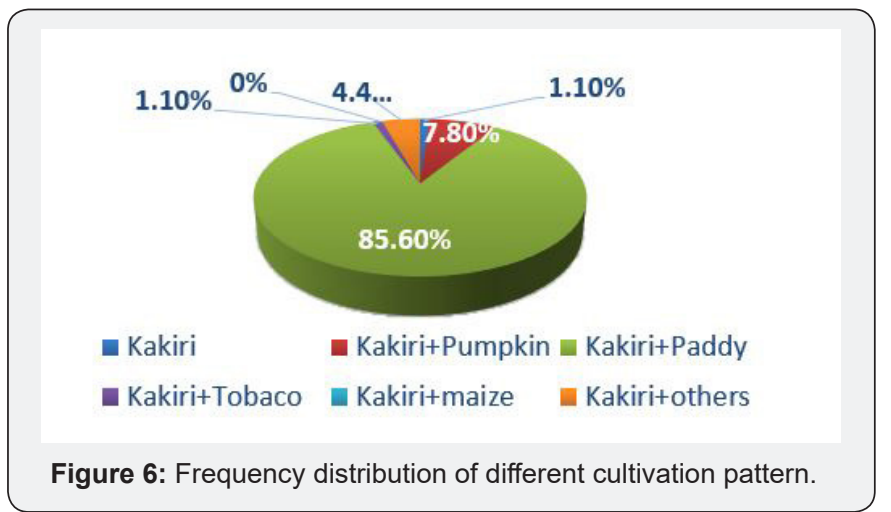

There was only $1.1 \%$ very small amount of contract farmers cultivate only in small cucumber. $85.6 \%$ very high amount of con- tract farmers cultivate small cucumber with paddy cultivation. Other contract farmers are cultivating small cucumber with paddy and pumpkin (Figure 6).

\section{Variation of Small Cucumber Cultivation Land with Dif- ferent Seasons}

According to the secondary data (organizational annual reports 2014-2017) it clearly shows land areas diminishing with the time [37]. Land amount in Yala season greater than comparing with yala-off and maha season. Lowest amount of small cucumber land can be seen in maha season (Figure 7). Contract farmers' satisfaction about small cucumber cultivation practices special reference to land preparation. In small cucumber cultivation very, simple land preparation can identify. Contract farmers were highly satisfied with land preparation practices.it was 57\%. 33\% were satisfied with land preparation (Figure 8).

\section{Variation of small cucumber cultivation land with different seasons}

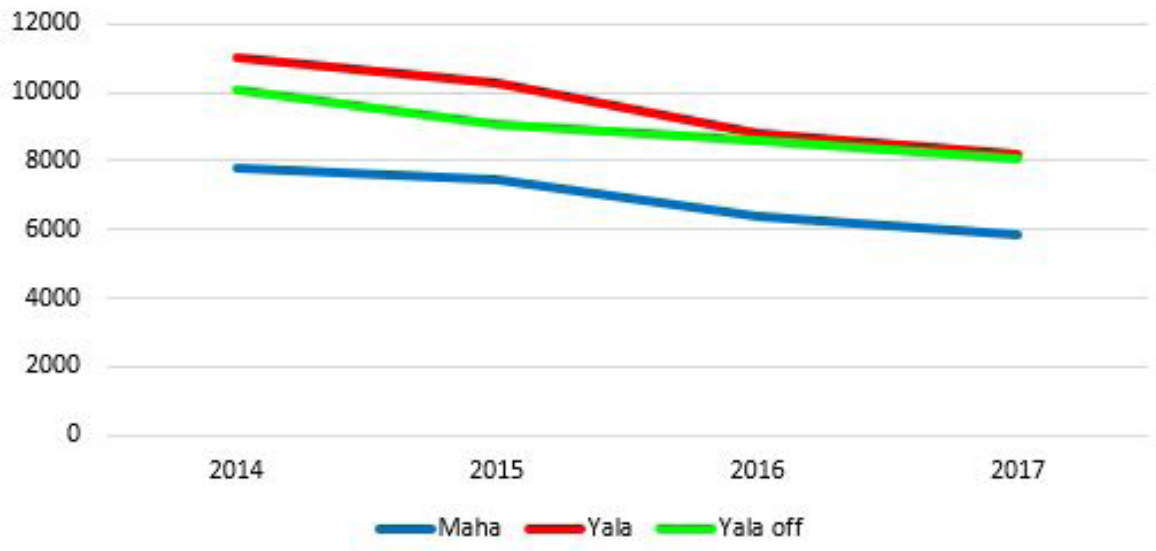

Figure 7: Frequency distribution of Small cucumber cultivation land with different season. 


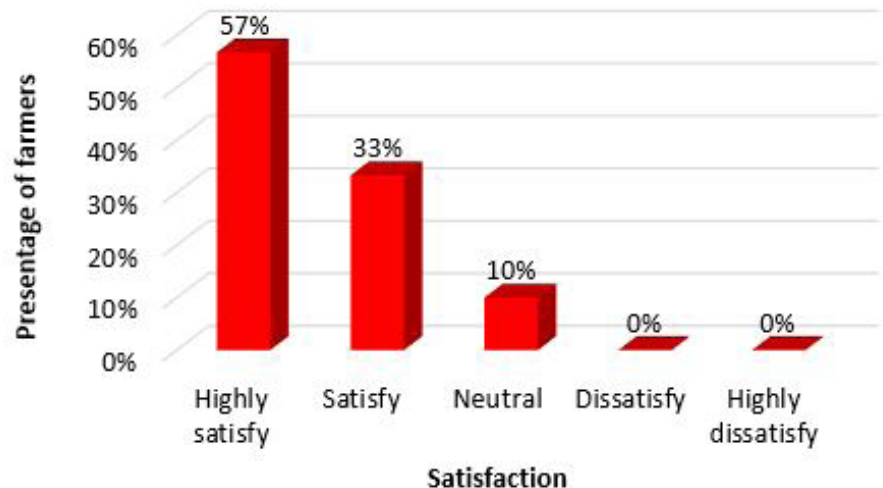

Figure 8: Frequency distribution of Contract farmers' satisfaction about small cucumber cultivation practices special reference to land preparation.

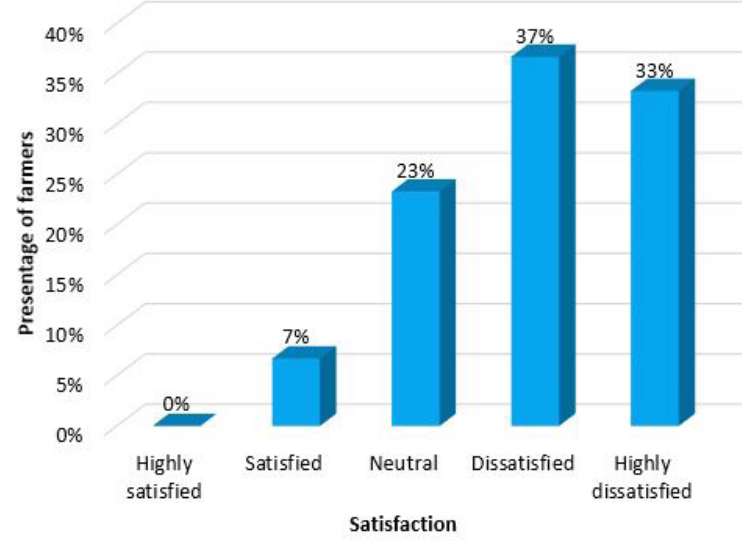

Figure 9: Frequency distribution of Contract farmers' satisfaction about small cucumber cultivation practices special reference to harvesting practices.

Contract farmers' satisfaction about small cucumber cultivation practices special reference to harvesting practices (Figure 9). Daily harvesting is vital in small cucumber cultivation. It is labor extensive practice and somewhat difficult practice

\section{Contract Farmers' Satisfaction About Income Receiving}

comparing to other crops. $37 \%$ of contract farmers under the dissatisfied category and 33\% under the highly dissatisfied level. There were only $7 \%$ contract farmers satisfied about harvesting practices [38,39].

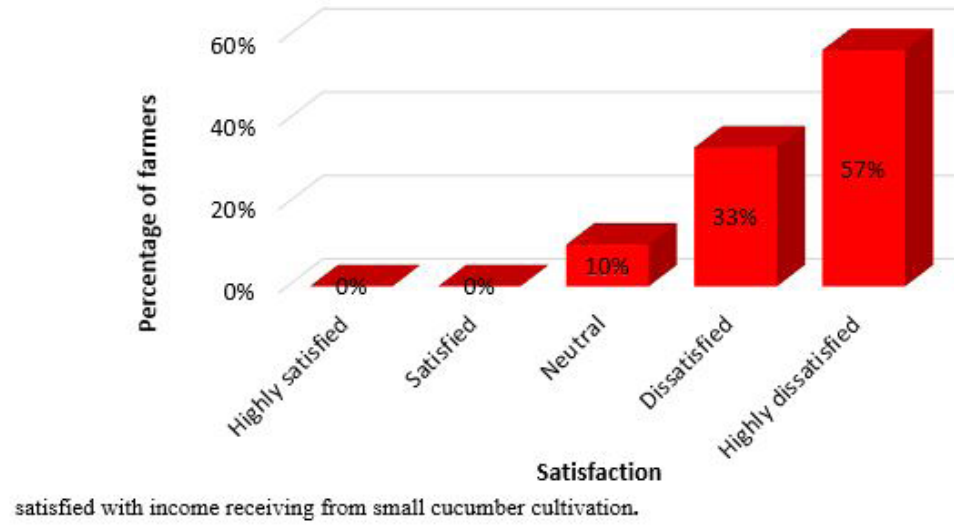

Figure 10: Frequency distribution of dissatisfied category there were no any contract farmers who satisfied with income receiving from small cucumber cultivation. 


\section{Annals of Social Sciences \& Management studies}

More than half (57\%) of contract farmers highly dissatisfied with their income coming from small cucumber cultivation.33\% of contract farmers under the dissatisfied category there were no any contract farmers who satisfied with income receiving from small cucumber cultivation (Figure 10).

\section{Contract Farmers' Satisfaction About Farm Gate Price}

Majority $(77 \%)$ of contract farmers dissatisfied with their farm gate price. $17 \%$ of contract farmers are highly dissatisfied with farm gate price [40-42]. There was no any contract farmer who satisfied with farm gate price (Figure 11).

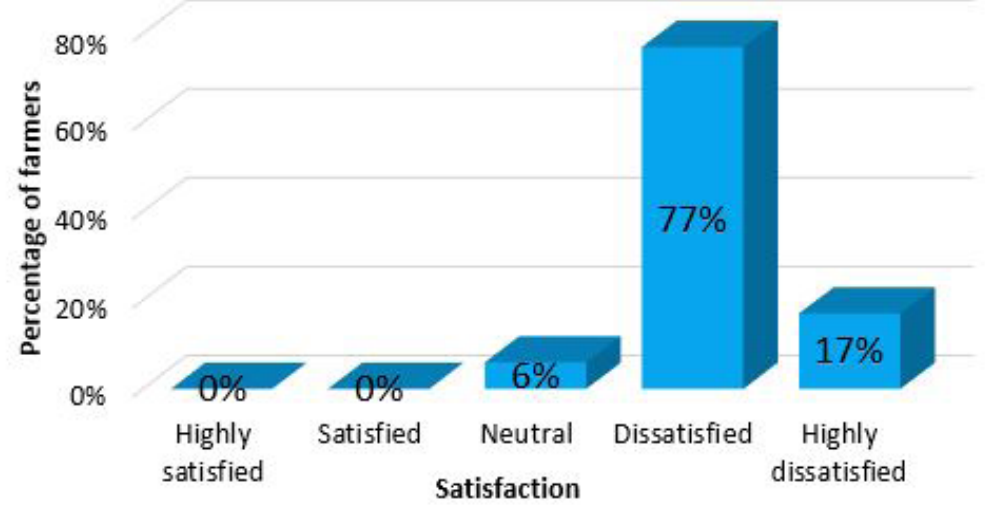

Figure 11: Frequency distribution of Contract farmers' satisfaction about farm gate price.

\section{Contract Farmers' Satisfaction About Pest Control Practices}

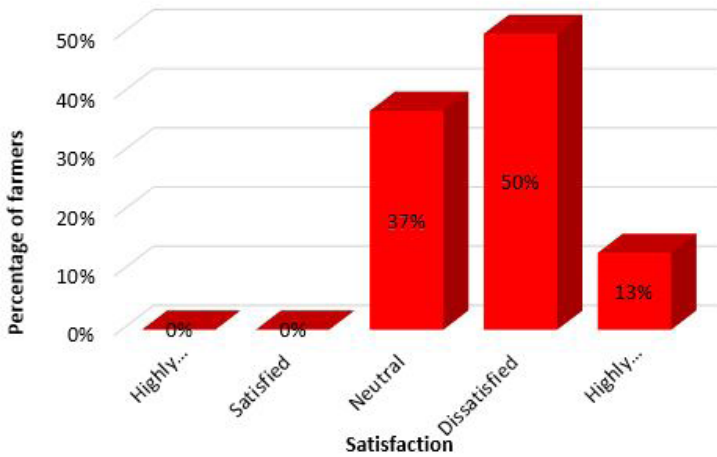

Figure 12: Frequency distribution of Contract farmers' satisfaction about pest control practices.

In small cucumber cultivation pest control is crucial practice. No any contract farmer satisfied with pest control practice (Figure $50 \%$ of contract farmers were dissatisfied about pest control 12). practices.13\% were highly dissatisfied with pest control practice.

\section{Contract Farmers' Satisfaction About Timely Receiving Money}

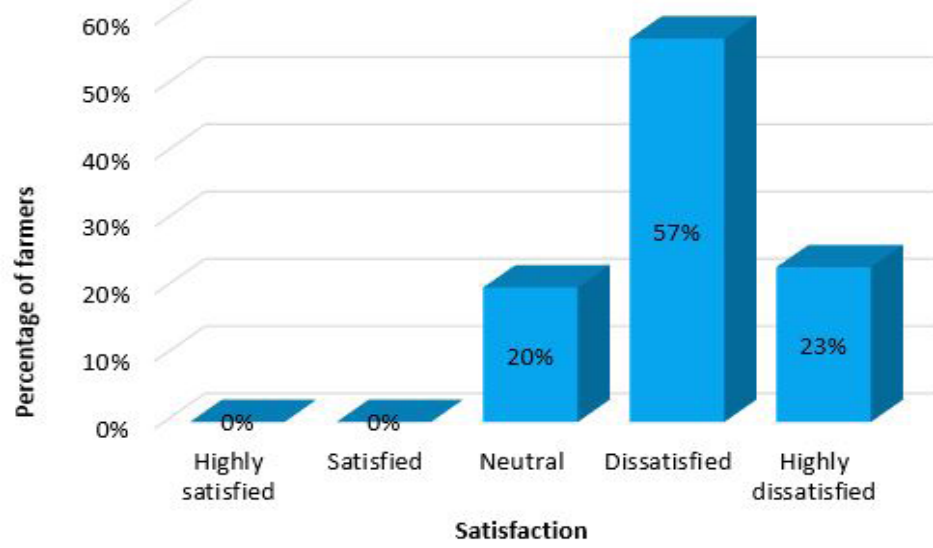

Figure 13: Frequency distribution of Contract farmers' satisfaction about timely receiving money. 
Majority (57\%) of contract farmer dissatisfied about timely money receiving. 23\% contract farmers highly dissatisfied about timely money receiving factor (Figure 13). Wilcoxon sign rank test for Training, Yield, Income, Farm gate price, Pest control, Money receiving. According to the Wilcoxon sign rank test $\mathrm{p}$ value is less Table 1: Farmers satisfaction about different criteria.

\begin{tabular}{|c|c|c|c|}
\hline Criteria & Test value & P value & Decision \\
\hline Satisfaction about training provide by organization & 6.63 & 0.0001 & Significant \\
\hline Satisfaction about yield receiving from small cucumber cultivation & 7.06 & 0.0000 & Significant \\
\hline Satisfaction about income receiving from cultivation & 7.57 & 0.0000 & Significant \\
\hline Satisfaction about farm gate price & 7.38 & 0.0000 & Significant \\
\hline Satisfaction about pest control practices & 6.96 & 0.0000 & Significant \\
\hline Satisfaction about timely money receiving & 7.42 & 0.0000 & Significant \\
\hline
\end{tabular}

Note: ${ }^{*}$ Significant $5 \%$ level, Source-own survey data.

\section{Conclusion and Recommendations}

Contract farmers are the key persons and main responsible person's development of cultivation. This become true when the contract farmer satisfied with their cultivation, it will directly have affected to the effective and efficiency of the contract farmers at the field. To achieve organizational goals and objectives it is vital to identify the individual contract farmer satisfaction level toward the cultivation. In this research, basically its main objective was to study the existing Small cucumber contract farming cultivation under pvt group of company and analysis the farmer satisfaction towards the of contract farming to reduce farmer dropout rate job satisfaction level.

Here in this study consider about 90 contract farmers in Ampara, Pollonnaruwa \& Thambutthegama areas. There is only limited number of researches are available to identify the satisfaction level of contract farmer with special reference to the Sri Lankan agricultural private organization. The aid of survey method for data gathering and it was utilized Pearson correlation analysis; Wilcoxon sign rank test and descriptive statistics for data analysis. One of the major conclusions that can be drawn from the study result is that difficulties occurred in cultivation practices especially in harvesting and pest controlling. Contract farmers satisfied about their training received and yield from small cucumber cultivation. Poor organizational practices like lower farm gate price, money not receiving timely to contract farmer reduce continues small cucumber contract farming.

\section{Recommendations}

The following recommendations are forwarded to organization to enhance the satisfaction performance of the contract farmers to the highest level.

a) According to the analyzed result concluded that the young age was significant in their satisfaction. Hence, in the farmer selection process give priority to that young farmer with agricultural background.

b) Enhance small cucumber farm gate price.

c) Develop standard system for effective money transferring to contract farmer. than $0.05(<0.05=\mathrm{p})$ in analyzed factors. Training, yield, income, farm gate price, control practices and timely money receiving factors were significantly affect on contract farmer job satisfaction (Table 1).

\section{Ex- "On the Spot Money Transferring Method"}

a) Develop innovative methods for harvesting and pest controlling.

Enhance the awareness about intergraded pest management instead to chemical application among contract farmers.

\section{References}

1. Anim, FDK (2010) Effects of extension services of firms offering contract farming: A case study of small-scale maize farmers in Limpopo province of South Africa. African Journal of Agricultural Research 5(7): 514-517.

2. Bautista, RM, Thomas, M (2006) Macroeconomic and agricultural growth. Trade and Macroeconomics Division Discussion. International Food Policy Research Institute, Washington, USA.

3. Binswanger, HP, Townsend, RF (2000) The Growth Performance of Agriculture in Subsaharan Africa. American Journal of Agricultural Economics 82(5): 1075-1086

4. Birner, R, Resnick, D (2010) The political economy of policies for smallholder agriculture. World Development 38(10): 1442-1452.

5. Birthal, PS (2008) Making contract farming work in smallholder agriculture. National Centre for Agricultural Economics and Policy Research, New Delhi.

6. Boocock, G, Shariff, MNM (2005) Measuring the effectiveness of credit guarantee schemes evidence from Malaysia. International Small Business Journal 23(4): 427-454.

7. Bratton, M (1986) Farmer organizations and food production in Zimbabwe. World Development 14(3): 367-384.

8. Delgado, CL (2006) Sources of growth in smallholder agriculture in sub-Saharan Africa: The role of vertical integration of smallholders with processors and marketers of high value-added items. Agrekon 38: 165-189.

9. Dorward, Kydd, Lofgren, Morrison, Poulton, et al, (2004) Institutions and policies for pro-poor agricultural growth. Development Policy Review 22(6): 611-622.

10. Aziri, B (2014) Corporate Governance: A Literature Review. Management Research \& Practice 6(3).

11. Evbuomwan, GO, Okoye, LU (2017) Evaluating the Prospects of The Anchor Borrowers programme For Small Scale Farmers in Nigeria.

12. Food and Agriculture Organisation of the United Nations (FAO) (2013) Enabling environment for agribusiness and agro-industries development: Regional and country perspectives. FAO, Rome, Italy. reforms in Zimbabwe: Policy complementarities toward equitable 


\section{Annals of Social Sciences \& Management studies}

13. Green, A (2003) Credit guarantee schemes for small enterprises: An effective instrument to promote private sector-led growth? Vienna: United Nations Industrial Development Organization (UNIDO).

14. Hazell, Poulton, Wiggins, Dorward (2006) The future of small farms: Synthesis paper. Paper presented at a Research Workshop organized by IFPRI, ODI and Imperial College, Wye.

15. International Finance Cooperation (IFC) (2011) Innovative agricultural SME finance models. DC: IFC, Washington, USA.

16. International Food Policy Research Institute (IFPRI) (2005) The future of small farms. Proceedings of a Research Workshop, Wye, Europe.

17. Juana, JS, Mabugu, RE (2005) Assessment of small-holder agriculture's contribution to the economy of Zimbabwe: A social accounting matrix multiplier analysis. Agrekon 44(3): 344-362.

18. Kangethe, SM, Serima (2014) Exploring challenges and opportunities embedded in small-scale farming in Zimbabwe. Journal of Human Ecology 46(2): 177-185.

19. Keyser, JC (2002) The costs and profitability of tobacco compared to other crops in Zimbabwe. San Francisco, CA: WHO Centre for Tobacco Control Research and Education.

20. Kocturk, OM, Cebeci, AN (2005) Contracting tobacco growing in Turkey. Journal of Agriculture and Rural Development in the Tropics and Subtropics. 106(2): 167-176.

21. Koranteng, KY (2010) Contract farming model of financing smallholder farmers in South Africa: The case of the IDC-KAT river citrus development scheme. Unpublished Research Report. Bellville: University of Stellenbosch Business School, South African.

22. Kumar, Kumar, KP (2008) Contract farming: Problems, prospects and its effect on income and employment. Agricultural Economics Research Review.

23. Leaver, R (2004) Measuring the supply response function of tobacco in Zimbabwe. Agrekon, 43(1): 113-131.

24. Lieping, Aiqun, Yunsheng (2007) On remote real-time communication between MATLAB and PLC based on OPC technology. In Control Conference.

25. Mafuse, Munyati, Mataruse, Manyumwa, Chimvuramahwe (2012) A comparative analysis of profitability of cotton production under contract and non-contract farming. Global Journal of Science Frontier Research Agriculture and Veterinary Sciences 12(10): 17-22

26. Makina (2009) Recovery of the financial sector and building financia inclusiveness. comprehensive economic recovery in Zimbabwe. Working paper series. Pretoria: United Nations Development Programme, South Africa.
27. Mandizha, T (2013) Govt to craft contract farming blueprint. Newsday.

28. Masakure, Henson (2005) Why do small-scale producers choose to produce under contract? Lessons from non-traditional vegetable exports from Zimbabwe. World Development 33(10): 1721-1733.

29. Minot, $N$ (1986) Contract farming and its effect on small farmers in less developed countries. Michigan: Michigan State University, USA.

30. Miyata, Minot, Dinghuan, HU (2009) Impact of contract farming on income: Linking small farmers, packers and supermarkets in China. World Development 37(11): 1781-1790.

31. Oya, C (2012) Contract farming in sub-Saharan Africa: A survey of approaches and issues. Journal of Agrarian Change 12: 1-33.

32. Richardson, CJ (2005) The loss of property rights and the collapse of Zimbabwe. Cato Journal 25(3): 541-565.

33. Saigenji, Zeller, M (2009) Effect of contract farming on productivity and income of smallholders: The case of tea production in North-Western Vietnam. Stuttgart: University of Hohenheim, Europe.

34. Simons, P (2002) Overview of smallholder contract farming in developing countries.

35. Suli, Bombaj, Suli, Xhabija (2013) What can be the role of publicprivate partnerships and the role of the collective action in ensuring sustainable smallholder participation in high value fruit and vegetable supply chains in Albania? European Journal of Sustainable Development 2(4): 323-332.

36. Tekere, M (2003) WTO agreement on agriculture: The implementation experience.

37. Tobacco Industry and Marketing Board (TIMB) (2012) National Tobacco workshop: Consolidating growth with equity. Harare: Tobacco Industry and Marketing Board, Zimbabwe, Africa.

38. Tobacco Industry and Marketing Board (TIMB) (2014) Annual Report. Harare: Tobacco Industry and Marketing Board, Zimbabwe, Africa.

39. Trading Economics, 2014. Zimbabwe Economic Performance Indicactors.

40. Woodend, JJ (2003) Potential of contract farming as a mechanism for the commercialisation of smallholder agriculture the Zimbabwe case study. Rome: Food and agriculture Organisation, Italy.

41. World Bank (2008) Agriculture for development. World Bank, Washington, USA.

42. Zikhali (2008) Fast track land reform and agricultural productivity in Zimbabwe. Working papers in economics no. 322. Gothenburg: School of Business, Economics and Law, University of Gothenburg.

This work is licensed under Creative Commons Attribution 4.0 License DOI: 10.19080/ASM.2019.02.555592

\section{Your next submission with Juniper Publishers will reach you the below assets}

- Quality Editorial service

- Swift Peer Review

- Reprints availability

- E-prints Service

- Manuscript Podcast for convenient understanding

- Global attainment for your research

- Manuscript accessibility in different formats

( Pdf, E-pub, Full Text, Audio)

- Unceasing customer service

Track the below URL for one-step submission https://juniperpublishers.com/online-submission.php 